\title{
MUNDO E FINITUDE EM HEIDEGGER
}

\author{
José Manuel Heleno \\ Centro de Estudos de Filosofia \\ (Faculdade Católica de Lisboa)
}

\section{A hermenêutica da facticidade (1919-1923)}

É para nós essencial mostrar como uma hermenêutica da facticidade, tal como é abordada entre 1919 e 1923, altura em que Heidegger leciona em Friburgo, ajuda a compreender o que será retomado, aprofundado ou alterado em Ser e Tempo. Mais do que ler as obras do jovem Heidegger, obsessivamente guiados por Ser e Tempo, mostrando sinais precursores ou tentando descobrir algo que as diferencie, é fundamental compreender essas obras em si próprias, nomeadamente a especificidade da noção de vida tal como é analisada em Friburgo

O objeto temático da investigação heideggeriana, expressamente considerada como visando o ser do ente no "sentido do ser em geral", e que faz da ontologia uma "tarefa de explicitação do ser em si mesmo", tem, ela própria, como pressuposto, um Dasein que existe de forma mundana. O facto de existir e de essa existência se temporalizar num mundo dado primordialmente, é um dos elos desta corrente ontológica que perde a sua solidez se acaso o quebrarmos. Heidegger não teme os círculos, considerando que a essência do pensar se exercita ao questionarmos às avessas (para utilizarmos uma expressão de Husserl). Há, deste modo, uma tentativa de sistematização por parte de Heidegger, ou seja, o intuito de pensar em totalidade as múltiplas manifestações do ser. É nesta aceção que ser, mundo, tempo e finitude são conceitos que se unificam numa forma de pensar que se pretende não apenas ontológica mas fundamentalmente ontológica.

As últimas lições de Heidegger em Friburgo, em 1923, nas vésperas de assumir a cátedra extraordinária de Filosofia na Universidade de Marburgo, começam por ter o título de Lógica antes de receberem o nome de Ontologia. 
Hermenêutica da Facticidade. Nessas lições, que preparam os temas que Heidegger desenvolverá em 1927, fala-se da ontologia como uma forma de interrogar vaga e indeterminada, ou seja, mais do que vincular a ontologia à rigidez de uma disciplina, tal como era encarada pelo pensamento clássico, visa-se o existir e o ser enquanto tal. Deste modo, a ontologia não se subdivide em regiões - natureza, cultura, mundo - mas assume claramente o existir fáctico como fundamento de todas as ontologias regionais. É o existir em cada ocasião, essa facticidade, nome que se dá ao "carácter de ser do nosso existir próprio", que apela à interpretação desse ser que tem esse modo de existir. Esta insistência no existir justifica a nova tarefa da hermenêutica, a de que mais do que a posse de conhecimentos, é antes caracterizada por um apreender existencial. Ora, se esta reformulação da tarefa hermenêutica é visível, tal pressupõe que se revejam os conceitos da tradição, nomeadamente as noções de homem e de mundo. Para Heidegger, "existir (viver fáctico) é ser no mundo". ' Ou então, "mundo é o que ocorre" (a expressão alemã begegnen significa "encontrar-se com", "aparecer", "ocorrer"). Por conseguinte, ao encontrarmo-nos com o mundo, cuidamos das coisas, o que é possível pela estrutura do Vorhabe (ter / haver prévio) e do Vorgriff (conceção prévia), modos privilegiados da vida fáctica.

Já em 1919, no seu primeiro seminário depois da guerra, intitulado Die Idee der Philosophie und das Weltanschauung problem, Heidegger chamava a atenção para a mundificação. O mundo é-nos dado significativamente, vivencialmente. $\mathrm{O}$ erro é pensar que se pode ter das coisas uma visão neutra, como se pudéssemos compreender as coisas na sua nudez, de forma "científica". Ora, as coisas têm sentido porque as percecionamos num mundo, quer dizer, adquirem significado, dizem-nos algo, porque estão inseridas numa estrutura significativa vital. "Estar-no-mundo" sinaliza essa impossibilidade de viver sem ser num universo de significações, o que se deixa traduzir pela inevitável "mundivivência" que nos define do nascer ao morrer. $\mathrm{O}$ facto de podermos falar sobre aquilo que percecionamos mostra que a própria linguagem desdobra esse complexo de significações, algo que precede qualquer teoria ou qualquer compreensão que se queira assumir como distanciada. Vale a pena, a este propósito, citar uma expressão de Karl Jaspers que, nos apontamentos sobre Heidegger acumulados ao longo de vinte anos, escreve a seu respeito:

O mais estimulante dos pensadores contemporâneos, altivo, imperativo, misterioso - mas que nos deixa vazios. ${ }^{2}$

\footnotetext{
${ }^{1}$ Heidegger, Ontología. Hermenéutica de la Facticidad. Madrid: Alianza Editorial, 1999, p. 104.

2 Rüdiger Safranski, Heidegger et son temps. Paris: Grasset, 1996, p. 150.
} 
Esta expressão de Jaspers tem, para nós, um valor crucial. De facto, com Heidegger apreendemos o mundo de outra forma ao sermos convidados a refletir sobre o que fazemos dia a dia, mas o que fica dessa compreensão do mundo circundante é um vazio, quer dizer, sentimo-nos incapazes de ir mais além na compreensão dessa vivência. A noção de ser, a sua presença, de tão luminosa, também nos ofusca, justamente porque ficamos cegos e mudos quando tudo indicava que estaríamos prontos para ver e falar de outro modo.

Reflitamos sobre a segunda parte de $A$ Ideia da Filosofia e o Problema da Concepção do Mundo, intitulada "Fenomenologia como ciência pré-teorética originária". Tendo como pano de fundo os contributos da fenomenologia e da escola de Marburgo, nomeadamente as reflexões de Paul Nartorp, Heidegger detém-se na noção de vivência, ou antes no es gibt, no há/dá-se que é essa "insignificância" que não merece, aparentemente, nenhuma atenção particular. Mas que significa o "há"? Que entendemos por "há algo", aqui, agora, pressupondo que há sempre algo aqui e agora? A questão do mundo é devedora do esclarecimento deste "há". A primeira tentativa é a de remetermos a pergunta "há algo?" para um sujeito psíquico. Afinal, só um sujeito pode fazer uma pergunta como essa. Contudo, como é que pensamos o objeto, a coisa, como sendo materialmente dada e estando "fora" do sujeito? Aparentemente, é no contexto do idealismo e do realismo que a pergunta "há algo" deve ser respondida. Para Heidegger, no entanto, nem o idealismo nem o realismo dão uma resposta cabal para esse espanto inicial que o "há algo" procura traduzir. Estamos, de imediato, num terreno onde há um sujeito e um objeto, embora nada se saiba das suas fisionomias.

Trata-se, de facto, de uma pergunta vivida. O "há algo" corresponde a uma vivência - e somos, de novo, lançados para a noção de um sujeito que vive esse "há". O es gibt tem qualquer coisa de impessoal, algo que se dá de forma indeterminada, apesar da nossa familiaridade. Heidegger escreve: "Não se nos dá nada psíquico nem nada físico". Ao querermos surpreender o "há" - precisamente o que existe de mais familiar em qualquer sujeito - não adianta falar em vivência, em processo psíquico que apreende o "há" ou até em falar no "eu", como se fosse o lugar em que o "há" se dá. $O$ "há algo" é tão natural que se dá como se não houvesse eu, mas fosse tão-só a própria vida e a intencionalidade concomitante.

Por conseguinte, é notória a preocupação de Heidegger, em 1919, de fazer da filosofia uma demanda em busca do essencial que é, ao mesmo tempo, o inútil e o insignificante. Contudo, só com esta demanda o mundo pode ser compreendido, quer dizer, só interrogando a vida, na sua espontaneidade, tem

${ }^{3}$ Heidegger, La idea de la filosofia y el problema de la concepción del mundo. Barcelona: Herder, 2005. 
sentido qualquer coisa como a filosofia. É, portanto, o mais simples e primitivo que a pergunta visa. Vejamos o que Heidegger escreve:

$E u$ pergunto: «Há ou se dá algo?». O «se dá» é um dar-se para um eu - e, contudo, não sou eu para quem e em direcção a quem se dirige o sentido da pergunta. ${ }^{4}$

O que o autor pretende dizer é que a minha vivência não se resume a um processo egóico, mas algo virado para o mundo que é, de imediato, significativo. Com efeito, olhamos para o que há e damos-lhes um significado, ou antes, para onde quer que me volte tudo é já mundano, tudo se mundifica (es weltet). Mesmo aqueles que não sabem o significado de uma coisa, por exemplo, para que serve ou o que faz ali, é sempre no contexto de uma mundificação que esta ou aquela coisa não têm significado ou têm um significado completamente diferente do habitual. Se não tem significado deve tê-lo, embora não se saiba qual é. Por conseguinte, o mundo é aquilo que tem um significado e é mundo por tê-lo. O essencial é não resumir este "há algo" a um eu, como se não fosse a subjectividade que estivesse em causa cada vez que atribuo significações. É evidente que o eu faz parte dessa mundificação, mas Heidegger quer ir mais longe (ou aquém) desse eu, como se quisesse surpreender o "há algo" na sua nudez. Quando objetivo, quando digo que há um objeto, quando falo de uma coisa separada de mim, distanciada, já se trata de uma experiência des-vivificadora (Ent-leben). Vale a pena citar o trecho por inteiro:

O objeto, o ser objeto como tal não me afeta. Eu já não sou o eu que de-termina. A vivência da determinação é apenas uma forma rudimentar da experiência vivida; é uma experiência des-vivificadora. O objetivo, o conhecido está, como tal, distanciado, desenganchado da autêntica vivência. Chamamos pro-cesso ao acontecer objetivado, ao acontecer como algo objetivo e conhecido; este acontecer passa simplesmente diante do meu eu cognoscente e estabelece com esse eu uma relação meramente cognoscitiva, de forma que este referência empobrecida ao eu fica reduzida a uma vivência mínima. ${ }^{j}$

O que está em causa neste trecho é a representação, a determinação dos objetos enquanto tais ou, numa palavra, a teoria. Heidegger quer mostrar que a atitude teórica é distanciada e re-presenta o objeto de uma maneira distinta da forma como se vive. Melhor: no quotidiano significativo há uma apropriação das coisas, não tanto um processo, quer dizer, uma representação das mesmas. É esta apropriação que é prioritária - e que se dá na mundificação. Nem há, verdadeiramente "coisas" e "objetos" nessa apropriação - pois se houvesse estávamos já no campo da representação. "Coisas" e "objetos" são processos,

${ }^{4}$ Ob. cit., p. 84.

${ }^{5}$ Ob. cit., p. 89. 
quando o que está em causa é a apropriação - momento singular que parece escapar a qualquer teorização.

Também tudo aquilo que Heidegger escreve sobre "Agostinho e o neoplatonismo", lição repartida em sessões de três horas proferidas na Universidade de Friburgo, no semestre de Verão de 1921, indica que a leitura fenomenológica do Livro X das Confissões de Santo Agostinho é fundamental para o desbravar da investigação. Com efeito, mais do que uma leitura histórica das Confissões, é importante desenvolver uma interpretação teológica e filosófica. A questão da vida fáctica, da memória, do cuidado, da vida mundana e da tentação, são temas abordados seguindo de perto os vários capítulos que constituem o Livro $\mathrm{X}$. Heidegger sublinha a forma como Agostinho abordou o problema da vida, quer enquanto tendência para a dispersão e tentação, onde avulta os vários tipos de concupiscência, quer a tendência para o indivíduo se encontrar e ganhar-se a si mesmo. Deste modo, o vivente é um ser histórico na medida em que é fáctico, em que se perde e ganha, e o "como" e o "poder" do seu agir é delimitado pela história efetiva em que se encontra. É esta ênfase no histórico-fáctico que permite compreender a sua mundanidade, ou seja, o conhecimento que vai adquirindo daquilo que o rodeia surge deste enraizamento primordial.

O que ressalta destas considerações é a importância conferida à vida fáctica e ao nexo de sentidos que ela desbrava. Ora, não poderemos dizer que a presença de Agostinho perdura ao longo da obra de Heidegger? Sabemos que o jovem Heidegger, por volta de 1916, viu fracassar os seus objetivos de obter a cátedra de Filosofia Medieval em Friburgo. Influenciado pelos estudos que levou a cabo nesse período, a verdade é que sempre o atraiu a "mística medieval". É neste sentido que convém estabelecer a genealogia de Ser e Tempo, genealogia que tem a sua origem em Aristóteles, Agostinho, Tomás de Aquino, Suárez e Husserl.

Embora a inquietude da alma, a sua tendência para se dispersar, justifique, para o autor das Confissões, a paz que o encontro com Deus pode proporcionar, o jovem Heidegger não se atém a este movimento em direção ao divino, preferindo retomar de Agostinho o que há de importante no cuidado, quer dizer, o facto de a inquietude ser portadora de uma experiência que não cessa de enriquecer a vida. Esta mostra à saciedade que o sujeito jamais se possui a si mesmo, quer dizer, que não podemos pensar numa plena apropriação de si. Como escrevem alguns comentadores:

A esta ideia de uma finitude radical que torna impossível a plena posse de si por si e necessário um cuidado constante, o pensamento de Heidegger permanecerá sempre fiel. ${ }^{6}$

\footnotetext{
${ }^{6}$ Annie Larivée \& Alexandra Leduc, "Saint Paul, Augustin et Aristote comme sources grécochrétiennes du souci chez Heidegger. Élucidation d'un passage d'Être et Temps ( $\$ 42$ Note)". In: Philosophie, «Heideggen», n. ${ }^{\circ}$ 69. Paris: Les Éditions de Minuit, 2001, p. 39.
} 


\section{Ser no mundo}

Anos depois, em Ser e Tempo, Heidegger escreve: "O ponto de partida correcto da analítica do Dasein consiste na explicitação desta constituição (ser-no-mundo)". ${ }^{7}$ Mas o ser no mundo só pode ser um fenómeno unitário. Ao abordar esta questão, Heidegger começa por denunciar tudo aquilo que impossibilita uma compreensão correcta deste fenómeno unitário. Assim, "ser-no-mundo" não tem o sentido de uma coisa dentro de outra, nem tão pouco o sentido de uma relação entre um sujeito (alma) e um objeto (mundo). "Um «ser-ao-lado» de um ente nomeado Dasein e de um outro ente nomeado "mundo», isso não existe", o que se deve entender como um reforço da convicção de que sujeito e objeto não são traduzíveis por Dasein e mundo. O que há de específico nesta modalidade existenciária fundamental é antes a familiaridade entre Dasein e mundo, dado como algo já conhecido, quer dizer, no seio da quotidianeidade o Dasein preocupa-se com as coisas, no sentido em que cuida delas. Por conseguinte, Heidegger esforça-se por dizer o mais imediato e, ao fazê-lo, pretende ancorar-se num solo ontológico e pôr entre parênteses todas as considerações ônticas e categoriais.

Resta saber se esta forma de filosofar, espécie de teologia negativa levada ao extremo, não antecipará uma dimensão distinta do ser que apenas tem legitimidade num horizonte poético e místico. É certo que o Dasein possui uma compreensão de si mesmo, o que se entende com um conhecimento médio na quotidianeidade mundana que o envolve. Ser no mundo indica o fenómeno da mundaneidade e esse conhecer imediato do Dasein fáctico. A noção de espaço - e as expressões que o designam: proximidade, tocar em, afastar-se, ao lado de, e tantas outras - é devedora deste modo de ser do Dasein que está no mundo e, por estar efetivamente, menciona ou designa os entes através de categorias.

A efetividade do factum Dasein, factum que é em cada caso cada Dasein, chamamos a sua «facticidade». ${ }^{8}$

A multiplicidade dos modos com que o Dasein é no mundo - produzir, encarregar-se, cuidar, abandonar, empreender, examinar, etc. - deixam-se unificar pelo cuidado. É enquanto cuida dos entes, de vários modos, que o Dasein é no mundo. Percebemos, enfim, que se trata de uma estrutura a priori, radical, que subjaz a todas as ciências, até à biologia, mas não deixamos de ter uma

\footnotetext{
${ }^{7}$ Heidegger, Sein und Zeit. Frankfurt am Main, Vittorio Klostermann, 1977, § 12 (sigla utilizada: SZ).

${ }^{8} \mathrm{SZ}$, ibid.
} 
sensação de inapreensível, de insatisfação e de vazio, porque, ao estabelecemos algo a priori, entendemo-lo, mesmo que no desejo de fundar, de ir à raiz, fiquemos com um conceito enevoado, um conceito que se torna inapreensível porque não se assume como conceito. Escreve Heidegger:

Esta «estrutura de sen» permanece ontologicamente inacessível (a de ser no mundo) embora onticamente seja experimentada como a relação entre um ente (o mundo) e outro ente (a alma). ${ }^{9}$

É neste aspecto que se revela fundamental a noção de útil. O útil não o é em si mesmo; algo é útil para isto ou aquilo. Há muitas coisas que podem ser úteis e em variadíssimos sentidos. E não é só no $\S 15$ de Ser e Tempo que Heidegger aborda esta questão, também o faz, justamente, a propósito da noção de mundo, nos Conceitos Fundamentais. Aí se fala no útil, no instrumento, no utensílio. $O$ útil remete para um complexo de úteis. Há uma rede de úteis: o que se maneja, manipula, o que está disponível ou à mão. Em nota de rodapé, no $\S 15$ de Ser e Tempo, alerta Heidegger que desde o semestre de Inverno de 1919-1920, se expôs repetidamente nos seus cursos a "análise do mundo circundante e em geral a «hermenêutica da facticidade» do Dasein".

Relembremos que desde as Interpretações Fenomenológicas de Aristóteles (1922) que sabemos que a "queda" (Verfallen; déchéance) não é um acidente na vida fáctica do Dasein, mas "uma modalidade essencial da vida", até o "destino mais íntimo que afecta a vida fáctica", ocasionado pela mobilidade essencial do cuidado, essa forma com que o Dasein se relaciona com o mundo, ao estar atarefado, virado para as coisas, entretido, trabalhando, exercitando a inevitável intencionalidade. Ao estar lançado no mundo, o Dasein preocupa-se com as coisas e arrisca-se a perder-se nelas. Esta é uma estrutura ontológica do Dasein, o seu modo de ser. O que fica por compreender é se a "queda" tem necessariamente uma conotação negativa. Para Heidegger ela seduz e acalma o Dasein, não tendo, assim, uma conotação meramente pejorativa. O Dasein sente-se seguro ao cair, deseja essa queda, esse esquecimento de si. Tal ajuda, parece-nos, a compreender a forma como as crenças se sistematizam e a concomitante necessidade de reduzir a estranheza, o desconforto, o perigo. E que dizer então da filosofia enquanto nostalgia, esse desejo de regressar a casa (Novalis)? Será também um anseio de segurança? O lado "impróprio" da "queda" reside no facto de a segurança impedir o regresso a si, quer dizer, afugentar a inquietude e arrastar o Dasein para a vida meramente preocupada. 


\section{Os conceitos fundamentais da metafísica}

Façamos uma referência ao curso de Heidegger intitulado Os Conceitos Fundamentais da Metafisica. Mundo - Finitude - Solidão. ${ }^{10}$ Tal interessa-nos porque aí se reflete sobre os temas que nos preocupam, ou seja, as noções de mundo, finitude e solidão. Considera Heidegger que a filosofia não é uma reflexão ao lado de outras: uma disciplina que ambiciona tornar-se científica, que se assume como uma "visão do mundo" ou que mostra o seu parentesco com a arte ou a religião. A filosofia, ao assumir a sua ambiguidade, não se atém a demonstrações e não tem como ideal o absoluto da verdade (mesmo matemática). Se a verdade da filosofia é o Dasein humano, deve então afastar-se dos falsos caminhos e assumir a vida em toda a sua plenitude. Ora, enraizar-se no Dasein, no seu destino, é reconhecer aquilo que há de perigoso e de arrebatador no ato filosófico. Mais do que reunir conceitos, Heidegger esforça-se por defender que a filosofia nos lança para uma viagem sem retorno, viagem em que o mundo surge às avessas (Hegel).

Esta atitude é compreendida se atendermos à especificidade da filosofia: ela é, como recorda Heidegger, servindo-se da expressão de Novalis, "nostalgia - instinto de estar por toda a parte em casa" (Die Philosophie ist eigentlich Heimweh-Trieb überall zu Hause zu sein). Mas que nostalgia é essa? Que casa é essa? A casa é o mundo, mundo que se dá em totalidade. Por conseguinte, filosofar, para o dizer poeticamente, é ter o impulso em regressar à casa do mundo, aos entes que são dados em totalidade. Mas se há nostalgia é porque, justamente, a finitude "é o modo fundamental do nosso ser". Descobrimo-nos finitos quando nos "tornamos finitos", quando compreendemos que estamos sós em face do mundo. Ora, é esta tripla exigência: a do mundo em totalidade, a da finitude que assim o encontra e a solidão de um ente que se encontra em face das coisas, que nasce uma comoção, ou seja uma tonalidade afetiva (Stimmung) com a qual estamos irremediavelmente comprometidos. O Dasein sente o abalo do mundo em totalidade mas, ao senti-lo, apercebe-se desse ente que ele mesmo é e se insere num todo que o abala. É desta situação que surge uma tonalidade, uma disposição, e não há filosofia que não surja dela.

Detenhamo-nos nesta noção de tonalidade. Destaquemos, em primeiro lugar, o facto de tonalidade ser um despertar e relacionemos esse despertar com o desvelar próprio da verdade. Se a tonalidade desperta, tal significa que a própria filosofia, enquanto expressão do modo de ser de cada Dasein na sua relação com as coisas, se dá numa disposição afetiva. Melhor: é a partir de

${ }^{10}$ Heidegger, Les concepts fondamentaux de la métaphysique. Monde - finitude - solitude. Paris: Editions Gallimard, 1992. 
um despertar para as coisas que elas mesmas se des-cobrem. O estar triste ou alegre, ou estar sempre numa disposição ou tonalidade, é o que permite ao mundo desvelar-se, descobrir-se enquanto isto ou aquilo. Neste sentido, não se estranha que nos Conceitos Fundamentais da Metafisica se referisse a tonalidade como uma espécie de melodia, um tom que dá consistência e possibilidade ao Dasein. Mais do que tomar consciência desse tom, dessa melodia que nos define do nascer ao morrer, o que se pretende é que ela, ao despertar, deixe ver alguma coisa de nós e do mundo que nos circunda. Não se trata, portanto, de epifenómenos, mas algo mais profundo, muito mais do que qualquer psicologia ou antropologia poderia analisar. Também em $O$ que é a Metafisica (1929) e no seu "Posfácio" (1943), se referia a finitude associada à angústia, o que, mais do que indicar um pendor niilista, assinalava antes uma experiência inerente ao Dasein: a do "ser como o outro em relação a todo o ente". É neste sentido que o nada que a angústia revela, longe de ser um fenómeno psicológico, é antes um estado afetivo que nos permite o acesso ao ser dos entes.

Também o tédio, esse "nevoeiro silencioso nos abismos do Dasein", é uma tonalidade que permite o acesso à compreensão do mundo, da finitude $\mathrm{e}$ da solidão. Nos Conceitos Fundamentais da Metafisica, as primeiras reflexões de Heidegger sobre o tédio são marcadas pela ambiguidade, não por insuficiência filosófica, mas porque a natureza do tema exige uma aproximação dialética. É por isso que ao lermos este texto sentimos o autor "pensar", ou seja, Heidegger vai circunscrevendo a questão, ora considerando o tédio como aquilo que se relaciona com uma disposição do sujeito, ora referindo coisas, pessoas ou acontecimentos que o desencadeiam, ora, enfim, considerando o tédio um ser híbrido que tem a sua parte subjetiva e objetiva. Não se trata, portanto, de tentar compreender o tédio de forma científica, quer dizer, de forma distanciada ou "neutra", coisa que inviabilizaria a reflexão filosófica enquanto tal. É que não só desejamos "adormecer" o tédio, afugentá-lo, como percebemos que ele está sempre aí, desperto. Compreendemos que a intenção de Heidegger não é de modo algum psicológica, como se fosse uma característica de certos indivíduos entediarem-se e outros não. Ao invés: trata-se antes de salientar que o tédio é uma forma profunda de compreender a relação que o Dasein tem com o mundo, a finitude e a solidão. Porquê? Porque o tédio indica uma relação determinada com o tempo, e é de tempo que teremos de falar se quisermos entender algo sobre o mundo, a finitude e a solidão.

O exemplo que Heidegger começa por nos oferecer é quando estamos, numa gare, à espera de um comboio. Se temos quatro horas pela frente, por termos perdido o comboio e aguardarmos a chegada de outro, sentimo-nos entediados. Sentimos então que temos de matar o tempo, apressá-lo, e olhamos constantemente para o relógio para ver se o tempo já passou. Mas o tempo 
parece que se alonga, sem sabermos o que fazer com ele, pois, nada nos consegue distrair, nem o livro que temos à mão, nem as imediações da gare, nem a "sala de espera". Queremos que o tempo passe depressa mas ele parece que se alonga, tornando-se mais pesado, mais lento. Procuramos, na verdade, um passatempo, qualquer coisa que o apresse e, ao fazê-lo, o possamos esquecer. Mas não é fácil descobrir um passatempo quando o tédio nos deixa vazios. Não descobrimos nenhum passatempo, não conseguimos relacionarmo-nos com nada e o mundo parece esquivar-se, pelo menos a curiosidade pelo mundo, o entreter-se com alguma coisa, algo que fizesse passar o tempo e o tornasse mais curto. As coisas arrastam-se e somos levados por esse arrastamento, incapazes de compreender o tédio em si mesmo, ou antes, sentimo-lo intensamente mas temos uma dificuldade enorme em compreendê-lo, em agarrá-lo. É ele, na verdade, que nos prende.

Trata-se então de saber se esta tonalidade é passageira ou se, ao invés, está profundamente enraizada em de nós. Nas reflexões que se seguem, o intuito de Heidegger é mostrar que o tédio é uma tonalidade profunda e não uma mera característica psicológica. É por isso que o "estar-no-mundo" do Dasein deve ser interpretado a partir de disposições, tonalidades, formas de viver e sentir o tempo que delimitam o mundo a partir de uma finitude. Deste modo, se nos sentimos aborrecidos é porque somos arrastados pelo tempo a ponto de nos sentirmos vazios. Mas é fácil de ver que nos sentimos vazios porque nos deixamos arrastar pelo tempo.

Contudo, se numa primeira forma de tédio, exemplificada pela espera na gare, há qualquer coisa de determinado, uma situação que origina o tédio a ponto de o sentirmos por qualquer coisa, há outra forma de tédio em que, aparentemente, não sentimos nada de aborrecido na situação que estamos a viver. Heidegger dá como exemplo o convite para passar a noite em casa de alguém, convite que aceitámos com agrado e em que tudo parece correr bem. A noite decorre sem que tivéssemos necessidade de um passatempo, pois nada parece haver de entediante. Conversamos, divertimo-nos e não sentimos o decorrer do tempo. Seria absurdo, por isso, falar em descobrir um passatempo para apressar o tempo quando acedemos ao convite. Todavia, se não há passatempo, nem por isso deixa de haver aborrecimento. Heidegger considera que podemos perceber que nos aborrecemos, quer dizer, que descobrimos posteriormente que a noite foi aborrecida, como se descobríssemos que o passatempo não está de todo ausente, embora esteja alterado, modificado, como se ele se manifestasse de outra forma. Portanto, se no primeiro caso deparamos com o aborrecimento, no segundo, como mostra o exemplo da soirée, parece que ele está ausente sem o estar verdadeiramente. No primeiro caso, o indivíduo entedia-se por qualquer coisa determinada, no segundo entedia-se de 
qualquer coisa que parece nada ter de aborrecido mas que, posteriormente, se descobre que é outra forma de aborrecimento. Neste último caso não é bem o vazio nem tão pouco a demora do tempo, mas antes uma forma de aborrecimento que só posteriormente se descobre como tal.

O curioso é a forma como o conceito de tonalidade afetiva (Stimmung) surge nos Conceitos Fundamentais da Metafisica. Em páginas anteriores Heidegger tinha-se ocupado com o esclarecimento da noção de metafísica: análise da physis, enquanto aquilo que cresce, se forma a si mesmo, se dá em totalidade, posteriormente análise do logos, como o que diz e revela o ente, por fim o meta, como o prefixo que a tradição congelou em "além", "depois de". Mas se a metafísica é uma interrogação inclusiva, tal significa que não apenas interroga o ente mas, nessa interrogação, inclui o próprio Dasein que a coloca. Heidegger defende que a escolarização da metafísica a partir de Aristóteles, a ideia de que se trata de uma indagação sobre o "supra-sensível", corresponde a uma metafísica tradicional que abandona o que de melhor possuía a visão aristotélica, ou seja, a necessidade de interpretar a metafísica a partir da filosofia primeira. Para Aristóteles, lido por Heidegger, a indagação da physis não se resume apenas ao ente em totalidade, mas interroga também a essência (ousia) do que é, o ser do ente. Este projeto da filosofia primeira acabou por sofrer transformações de monta, escolarizando-se, tornando-a sinónima de indagação teológica e de supra-sensível. Retornar à metafísica é então descobrir a tonalidade fundamental do Dasein, isso que permite compreender a forma como o tédio é uma tonalidade profunda, que, como um nevoeiro silencioso, se entranha nos abismos do Dasein. Por conseguinte, a explicitação da noção de tonalidade afetiva surge depois da explicitação de metafísica e antes da abordagem das várias formas de tédio que circunscrevem o Dasein.

Mas que nos mostra o tédio profundo? A unidade entre mundo e solidão. É a finitude do Dasein que ressoa na tonalidade fundamental do tédio profundo; é ela que nos permite compreender que as três questões - mundo, finitude, solidão - remetem para o tempo. Comecemos pelo esclarecimento da noção de mundo - algo que Heidegger já tinha feito em 1928 com A Essência do Fundamento. Com efeito, tanto podemos pensar o mundo a partir da história do conceito, como podemos fazê-lo indagando sobre o mundo na sua quotidianeidade, sobre o que está à mão para o Dasein imerso no quotidiano atarefado, tema que tinha sido abordado em 1927, em Ser e Tempo. Todavia, nos Conceitos Fundamentais da Metafisica, procede-se a um exame comparativo entre três teses: "A pedra é sem mundo"; o "animal é pobre em mundo" e "o homem é o configurador do mundo". Se a tonalidade profunda dá o tom; se ela é compreendida a partir do aí, então o homem pode compreender o ente enquanto ente, configurar o mundo num horizonte de possíveis, alargá-lo em 
função das significações que lhe confere. Se para uma pedra o mundo está ausente, para o animal a sua pobreza reside no facto de estar privado do mundo enquanto tal. Como escreve Heidegger:

A pobreza em mundo é uma privação do mundo. A ausência de mundo é uma constituição da pedra tal que esta não pode mesmo ser privada de qualquer coisa como o mundo."

Por conseguinte, não se trata aqui de uma valoração, como apressadamente poderíamos deduzir partindo da expressão "pobreza". Não se trata de facto de estabelecer uma hierarquia de valores, como se o mundo se revelasse para o homem de uma forma superior, rica, face à pobreza do animal e da penúria da pedra. Se a pedra é sem mundo, o animal sente-o mas de uma forma empobrecida, como se a rocha onde o lagarto se aquece não pudesse ser sentida como rocha. A pobreza está na ausência deste como, diferente do homem, capaz de configurar em totalidade e sentir o ente como ente.

Pergunta-se em os Conceitos Fundamentais da Metafisica: Podemo-nos transpor no animal? Podemo-nos transpor na pedra? ${ }^{12} \mathrm{O}$ problema reside em tentar saber como podemos compreender outros entes, ou seja, em que medida nos podemos transpor neles e compreender o seu mundo. Deste modo, saber o que é o mundo envolve a noção de poder compreender mundos possíveis, os supostos mundos que caracterizam outros entes. Para Heidegger a transposição do homem no animal é possível em princípio, mas é manifestamente impossivel numa pedra. Contudo, a questão da transposição do homem noutro homem é uma questão supérflua, pois o "homem é, de imediato, ser em conjunto com outros". ${ }^{13} \mathrm{E}$ mais à frente: "Ser transposto noutros faz parte da essência do Dasein humano". Mas dizer que nos podemos transpor no animal não significa que temos acesso ao seu mundo. Na verdade, o animal tem e não tem um mundo, ou seja, a esfera em que se move não é aquela a que os humanos denominam mundo. Ao transpor-se no animal o homem continua a ser si mesmo embora acompanhe o animal. De acordo com Heidegger, transpor significa: "acompanhar aquilo que é e como é o ente". Portanto, podemos fazer como se fossemos o outro ente, mas isso não cauciona (no caso do animal) em falar-se de mundo, pois só o homem possui verdadeiramente um mundo.

Parece-nos, por conseguinte, que a noção de tonalidade afetiva marca a finitude do Dasein, ou seja, estar lançado no mundo é estar afetado por ele de tal forma que a resposta (antworten) ao ser do ente significa correspondência

\footnotetext{
${ }^{11}$ Heidegger, Les concepts fondamentaux de la métaphysique, ed. cit., p. 292

${ }^{12}$ Ibid., p. 298 e sgs.

${ }^{13}$ Ibid., p. 307.
} 
(Ent-sprechen). Dizemo-lo parafraseando Que é isto - a Filosofia? (1955), salientando que viver é estar em correspondência com o ser do ente, só que "raramente somos atentos à inspiração do ser". A correspondência é um comportamento - e é isso, justamente, a filosofia, quer dizer, a disponibilidade para ser sensível a esse apelo do ser do ente, essa forma de correspondência que escuta a sua voz.

\section{A finitude do tempo originário}

Se o mundo se revela nessa abertura do Dasein, lançado e caído a todo o momento, é porque isso sinaliza a finitude do tempo originário. A noção de mundo em Heidegger não pode ser pensada sem a finitude que caracteriza o Dasein, pois a possibilidade de ser é, em si mesma, uma possibilidade que só tem sentido no quadro da finitude. Heidegger pensa a finitude a partir da temporalidade, da morte e da estrutura ontológica do Dasein. É pelo facto de o tempo e de o homem serem finitos que o conhecimento do ser é possível. Neste sentido, toda a infinitude é derivada, não originária e negativa. Esta perspetiva radicaliza a convicção de que pretender pensar a infinitude do tempo significa esquecer a sua finitude originária.

$\mathrm{Na}$ interpretação de Kant, Heidegger sublinha esta perspetiva, ao considerar que as intuições são dadas e não criadas o que mostra o pendor fenoménico de todo o conhecimento. Todavia, se Heidegger insiste em ler Kant dessa forma, sublinhando que a ele se deve a ênfase na finitude de todo o conhecer, nem todos, como Cassirer, concordam com esta perspetiva. De facto, a lei moral, os anseios metafísicos do pensar, indicam que Kant viu na lei moral uma promessa de infinitude, ou melhor, essa lei moral não seria compreensível deslocada do horizonte da infinitude.

Pensar a finitude é chamar a atenção para essa possibilidade da impossibilidade de ser, ou seja, a morte própria. Se a morte é o selo da finitude isso assinala que ninguém pode morrer por mim. Mesmo a morte dos outros não me dá o "propriamente morrer", como se apenas o Dasein pudesse conhecer a finitude na sua radicalidade, pois é o "si mesmo" que o define que lhe dá essa feição ontológica. A atitude de Heidegger em relação a uma biologia, antropologia ou sociologia da morte é a de que essas aproximações ônticas ao fenómeno da morte não nos podem oferecer a experiência ontológica da mesma.

A morte não é assim uma noção entre outras, mas sim aquela que permite compreender a finitude do Dasein. Pelo facto de o fim do ser-no-mundo ser a morte, morrer é então deixar de ser-no-mundo ou, como diz Heidegger em Ser e Tempo (§ 48), perder o "ser do aí". Ora, viver no mundo é poder ser, não só um poder ser impróprio, imerso na quotidianeidade, mas um poder ser 
próprio que a noção de morte permite assumir. É esse poder ser que nos permite compreender que o fim do Dasein tem de ser encarado pelo ainda não. Com efeito, o Dasein nunca realiza, do nascer ao morrer, todas as suas possibilidades, O ainda não é estrutural. Se a morte encerra o Dasein é porque põe fim ao ainda não - o que pode acontecer a qualquer momento. É este o sentido da finitude: o poder ser, consubstanciado no ainda não, e a certeza indeterminada de que, a qualquer momento, o Dasein pode deixar de ser. É também importante relacionar esse poder ser e a finitude com o cuidado. Na sua preocupação atarefada, o Dasein pode morrer, ou seja, deixar de estar aí e de cuidar dos entes. Contudo, não se pense que esta morte é algo por realizar. A incompreensão que ocasionaram as páginas de Ser e Tempo dedicadas ao fenómeno da morte, deve-se a um desatender que a morte é apenas uma possibilidade que o Dasein deve assumir, e de forma alguma algo que tenha de realizar. A morte, ao ser a sua possibilidade mais própria, é aquilo que interpela o Dasein e lhe dá uma singularidade. Melhor: a morte dá corpo à finitude e, no mesmo movimento, singulariza um existente.

A propósito das interrogações kantianas sobre o que posso saber, o que devo fazer, o que me é permitido esperar e, por fim, o que é o homem, considera Heidegger, na leitura que faz em 1929, que o poder, o dever e o esperar são sinais da finitude humana. Na verdade, a razão não é finita porque põe estas questões mas põe estas questões devido à sua finitude. ${ }^{14}$ Deste modo, a preocupação com o fundamento da metafísica só tem sentido devido à finitude do humano, de tal modo que ela "se torna ela própria um problema". A importância destas considerações torna-se patente quando Heidegger afirma:

Sob o título de ontologia fundamental, está já incluído o problema da finitude no homem como o elemento decisivo que torna possível a compreensão do ser. ${ }^{15}$

E numa expressão digna de ser repensada, afirma no término da sua reflexão que "nada repugna mais à ontologia que a ideia de um ser infinito".

\section{Dasein e mundanização}

Heidegger jamais deixará de insistir nesta relação que o Dasein, ente finito, tem com o ser. Mas não terão as coisas, os animais, relação com o ser? Se dissermos que as coisas existem estamos, certamente, a caracterizar um modo de ser das coisas que se relacionam primordialmente com o Dasein que nós próprios somos. Com efeito, as coisas nem sequer sabem que existem

${ }^{14}$ Heidegger, Kant et le problème de la métaphysique. Paris: Tel/Gallimard, 1981, p. 273.

${ }^{15}$ Ibid., p. 288. 
e não têm, por conseguinte, nenhuma relação com qualquer tipo de ente. Mas se dissermos que elas existem, afirmamos então qualquer coisa que tem a ver connosco - que existimos - e um modo de ser que lhes é próprio. É assim que estamos no grau zero dos conceitos: não há coisas ao lado, acima ou sobre outras coisas. Não há, portanto, mundo. O que as coisas podem mostrar é a importância do mundo para esses entes que as designam (o Dasein).

Interroguemos: será correto dizer, como o faz Heidegger, que o Dasein tem uma certa relação com o ser? Na verdade, é a única relação - pois também os animais não se relacionam com o mundo. Assim, só o Dasein existe. Pode até dizer-se que a sua essência (quididade) está no seu existir. Mas o que impressiona, digamo-lo desde já, é que essa existência é minha - a propriedade de ser minha é a Jemeinigkeit - o que os franceses traduzem por miennéité. O suposto individualismo de Heidegger, a sua forma "aristocrática" de filosofar, a teimosia em centrar-se no Dasein - e não na comunidade ou no espaço público, a não ser de modo impróprio - é, aparentemente, descabida. Na sua perspetiva, cada Dasein está só, não por uma contingência qualquer mas porque existir é existir aqui, quer dizer, apenas nesta solidão irremovível pode cada Dasein assumir a sua existência. Ninguém pode existir (nascer, morrer) por mim.

Façamos duas sínteses preliminares: não há um sujeito, um homem, e depois o mundo. $\mathrm{O}$ mundo, a vida fáctica, antecipa-se sempre ao sujeito e às coisas, quer dizer, a própria noção de sujeito e de coisa pressupõe inevitavelmente um mundo. Isso é aquilo que Heidegger chama, em 1929/30, em Os Conceitos Fundamentais da Metafisica, uma verdade ontológica. A crítica ao logos apofântico pressupõe um mundo. Mas, que mundo é esse? Há os entes e o ser dos entes, mas que ser é esse? É preciso atender, desde já, a esta insistência em erguer uma filosofia a partir do Dasein e a forma como este está lançado num mundo. $\mathrm{O}$ não cartesianismo de Heidegger não reside meramente no facto de o cogito cartesiano não ser elucidado enquanto tal, mas sim na forma como Dasein, mundo e facticidade se encontram imbricados. ${ }^{16}$ Várias questões nos assaltam: primeiro, o que haverá de errado em outras perspetivas que se digladiam para erguer um mundo? Por que não a linguagem, o mundo em si mesmo, o eu? Poderá Heidegger escapar à suspeita de conceder ao Dasein uma importância excessiva?

Outra questão que merece a nossa atenção é a de saber em que medida a noção de diferença ontológica nos pode esclarecer sobre o mundo? O ente, considerado como ente, é o ponto de vista ôntico. Se interrogarmos o ser do ente, aquilo que faz como que o ente seja aquilo que é, estamos então no domínio 
ontológico. Compreender o ente enquanto ente, a sua estrutura, é a ontologia. Ora, o mundo só pode ser dado quando se pretende descobrir essa estrutura ontológica. E quem o poderá fazer senão o Dasein, aquele que existe? ${ }^{17}$ Fundamentais são as noções de "ente intramundano" ou "mundaneidade", pois jamais podemos compreender o que significa "mundo" sem um Dasein que, por existir, se relaciona de imediato com outros entes e interroga o sentido do ser, essa estrutura que faz com que cada ente seja aquilo que é. Mas não serão estas distinções retóricas? Que haverá aqui de essencial? ${ }^{18}$

$\mathrm{Na}$ "gramática" do mundo, quer dizer, naquilo que faz com que um mundo seja um mundo e se estruture como se estrutura, teremos então de aceder à forma como o Dasein, enquanto existente, se situa de imediato no mundo. É a este propósito que surgem noções como preocupação (Besorgen) e utensílio (Zeug). Com efeito, acedemos ao mundo porque nos preocupamos com as coisas e as utilizamos no dia-a-dia. As coisas são pragmas, modos de ser que se relacionam com o agir humano. Para que haja um mundo há então que existir coisas com as quais nos preocupamos e de que nos servirmos para existir. Esta é uma das lições de Ser e Tempo. Sublinhemos, no entanto, esta ideia de "utensílio", de "servir a" ou "para", que nos permite compreender o "mundo" de forma não teórica. O mundo, poderíamos dizê-lo, é habitado antes de ser conhecido. ${ }^{19}$

Cada vez mais se afigura premente saber o que entende Heidegger pelo facto de o "mundo" ser pressuposto. Tudo aquilo que podemos dizer sobre os entes pressupõe sempre um mundo. Como compreender "mundo" sem nos atermos a noções como "horizonte", "totalidade" ou "inter-relação"? Mas não será isso adiar a dificuldade, trocar um problema por outros? $\mathrm{O}$ acesso ao ente dá-se num fundo mundano. O Dasein mundaniza as coisas - e é inevitável que o faça. O erro é tentar compreender o ente por si mesmo, isolado, e pensar que o acesso a esse ente se dá pelo conhecimento. Só conhecemos se tivermos uma mundivivência que estruture esse conhecimento. Também vislumbramos que esse mundo não se dá à parte: ele dá-se em cada ato percetivo é, aliás, a sua condição. Por outro, nada percebemos se não atendermos ao facto de o Dasein estar sempre e já aí, imerso na quotidianeidade.

A preocupação, o utensílio, o "ser-à-mão", são conceitos forjados por Heidegger para chegar a uma compreensão do fenómeno mundo. Mas por que

${ }^{17}$ Cf. Walter Biemel, Le Concept de Monde chez Heidegger. Paris: Vrin, 1950, p. 19.

${ }^{18} C f$. as várias significações de "mundo" em W. Biemel, ibid., pp. 20-21.

${ }^{19}$ Seria interessante, aliảs, confrontar esta conceção com a ideia de rêverie e de imaginação produtora em Bachelard, imaginação que se prende invariavelmente com o vivido. Por exemplo, diria Bachelard que o espaço antes de ser geométrico é um espaço habitado - como Heidegger, aliás, defenderia. 
não conceitos como desejo ou até necessidade? Onde anda o desejo na filosofia de Heidegger? É interessante que o acesso ao mundo se faça atendendo àquilo que o homem é no dia a dia. É no e pelo quotidiano que chegamos a uma compreensão do ente e do ser do ente.

Em "O Tempo da Imagem do Mundo", ${ }^{20}$ mostra-se a estreita conivência entre a metafísica e o projeto da modernidade. Não se estranha, por isso, que as ciências, na sua progressiva especialização, visem capturar o ente objetivando-o. Assim, a necessidade de re-presentar o ente significa que só vale como conhecimento o que é objetivado. Este projeto assinala o pendor para se explicar o mundo objetivando-o, o que, longe de dar uma explicação cabal, encerra o ente numa imagem, aprisionando-o numa suposta distinção entre sujeito e objeto. No limite, procuram-se imagens do mundo. Mas, escreve Heidegger, "a imagem do mundo seria como que uma pintura do ente em totalidade". ${ }^{21}$ Contudo, ao querer uma "imagem" do ente perde-se o seu ser. $\mathrm{Na}$ sua obsessão em compreender o mundo concebido como uma imagem, sistematiza-se o ente em totalidade, de tal forma que "o ser do ente é procurado e encontrado no estar-representado [Vorgestelltheit] do ente". E mais à frente afirma-se que "o mundo se torne imagem e que o homem, dentro do ente, se torne subjectum, é um e o mesmo processo". E ainda: "O processo fundamental da modernidade é a conquista do mundo como imagem". ${ }^{22}$

\section{6. $O$ apocalipse do real}

Peter Sloterdijk ${ }^{23}$ devia certamente conhecer a expressão de Rüdiger Safranski quando este último refere, a propósito dessa exigência de mundificar o mundo, que Heidegger "repete um movimento que tem origem nos finais do século XIX: a descoberta da realidade real. Ai descobriu-se a economia por detrás do espírito (Marx), a existência mortal por detrás da especulação (Kierkegaard), a vontade por detrás da razão (Schopenhauer), o impulso por detrás da cultura (Nietzsche, Freud) e a biologia por detrás da história (Darwin)". Afirmamo-lo porque Sloterdijk baseia a sua reflexão na mesma perspetiva de Safranski, embora sem o citar. De facto, interessa a Sloterdijk argumentar que há uma "política de Heidegger", e que ela é compreendida a partir do "apocalipse do real", ou seja, de que há todo um movimento espiritual que se inicia ainda antes do século XX que aposta na "omnipotência

\footnotetext{
${ }^{20}$ In Heidegger, Caminhos de Floresta. Lisboa: Fundação Calouste Gulbenkian, 2002.

${ }^{21}$ Ibid., p. 112.

22 Ibid., p. 117

${ }^{23}$ Cf. "La politique de Heidegger". Magazine littéraire, 9 (mars-avril 2006): 42-45.
} 
e na omnipresença de um real que se constrói de baixo para cima". Esta importância conferida ao real, neorrealismo que desconfia de toda a filosofia que parte de cima para baixo, é o solo em que se entranha a perspetiva heideggeriana. ${ }^{24}$ Como escreve Sloterdijk:

Tanto como os neorrealistas do século XIX tinham feito avançar o apocalipse do trabalho e da animalidade, Heidegger, no seu período neorrealista tempestuoso, distingue-se pelo seu apocalipse da temporalidade existencial, segundo o qual o sentido da existência abre-se somente, num primeiro tempo, a partir do ser-para-a-morte. ${ }^{25}$

O problema, no entanto, é o de saber se há ou não preocupação, por parte de Heidegger, com a "temporalização coletiva", ou seja, se podemos ou não considerar que Heidegger não pensou, porque não quis ou não pôde, a história e a dimensão coletiva (política). Se é sempre o Dasein que está em causa - e a ontologia que se constrói, do cuidado ao aborrecimento, da facticidade ao ser-para-a-morte, o assume decididamente -, como podemos então pensar a dimensão coletiva, o tempo da vida como sendo o tempo de um povo e a história que encarna a temporalidade de outro modo? Trata-se de saber como podemos inscrever a história do Dasein numa História, ou seja, de pensar o supra-individual. Considera Sloterdijk que Heidegger o tentou de várias maneiras, muitas delas contraditórias.

$\mathrm{Na}$ parte final deste belo texto, Sloterdijk argumenta que as noções de Stimmungen (tonalidades profundas) e de Ergriffenheit (comoção ou emoção), que se prolongam para além de Ser e Tempo, acabam por nos ajudar a compreender o homem contemporâneo e a forma como vive a sua época. Ora, este diagnóstico resume-se meramente a uma época ou mostra, ao invés, que todas as épocas e, por conseguinte, a História, é atravessada pela inautenticidade, quer dizer, pelo aborrecimento, pelo vazio, pela tagarelice mundana e pela queda no "se"? Parece-nos que a construção de uma ontologia torna descabida a circunscrição das estruturas do Dasein ao efémero de uma época. Se a assim

${ }^{24}$ Como era o mundo onde Heidegger nasceu e viveu? Filho de Friedrich Heidegger, um adegueiro-chefe e sacristão na Igreja de São Martinho, em Messkirch, falecido em 1924, Heidegger depositou um exemplar manuscrito de Ser e Tempo no leite de morte da mãe, em 1927 , justamente no ano em que acaba de ser publicado. Messkirch era uma pequena vila com fortes tradições religiosas, o que ajuda a compreender a infância e a adolescência de Heidegger, como também as bolsas de que beneficiou para continuar os seus estudos liceais em Constança e em Friburgo. Tudo indicava que Heidegger estaria destinado a uma carreira eclesiástica, se não fossem os seus "problemas cardiacos". A noção de um Dasein que se temporaliza, que pratica a "des-eternização" e que sente a sua própria mortalidade, mostra como Heidegger se tinha libertado das influências religiosas que recebera, abraçando o pathos kierkegaardiano e a força do real que se fazia sentir por todo o lado ( $c f$. Safranski, ob. cit.).

${ }^{25}$ Sloterdijk, art., cit., p. 43. 
fosse, toda a solidez de Ser e Tempo se desvaneceria. Mas esta visão "trágica" da História, que parece confirmar-se à medida que o tempo avança, será outra maneira de falar no "fim da história" e desse deserto que foi incessantemente referido tanto por Nietzsche como por Hannah Arendt?

Se Sloterdijk não fala na "viragem" nem se refere ao "acontecimento-apropriação" (Ereignis), é porque não toma em consideração aquilo que, na "viragem", podia existir de "político" no pensamento heideggeriano. Contudo, em vez de abraçar uma perspetiva "política", depois da sua retratação e do abandono do claro conservadorismo de outrora, eis que Heidegger nos fala da história do ser e vê o Dasein como um dos acontecimentos nessa história. É tempo, portanto, de se entranhar em formas poéticas de pensar, de propor a serenidade, de afirmar que a História da metafísica, como história da presença, é essa longa noite do ser que continua a envolver-nos. Não há, portanto, nenhum pensamento "político", mesmo que Heidegger tenha escrito uma carta sobre o humanismo. O que há é ainda uma forma mais poética e filosófica de pensar, um dizer a quadratura (mortais, deuses, terra e céu); um considerar que servimos o ser e que nos devemos remeter para um destino onde pontifica a humildade e a aceitação.

\section{Observações críticas}

Esbocemos uma síntese de observações críticas.

Poderemos compreender a finitude sem a noção de infinitude? Querer "eliminar"a infinitude relegando-a para o campo do não originário e do derivado, é cortar cerce um problema que assume contornos que o não admite. "Eliminar" a noção de infinitude é, de algum modo, rever de forma radical o sentido da finitude - esse sentido que se revelará inesperado e não apenas uma mera simetria da infinitude. Não se pode manter um dos pólos eliminando o outro, mesmo considerando as alterações substanciais que o sentido da finitude acaba por sofrer. Um traço que se mantém em Heidegger é a importância dada à finitude, o que remete para um quadro teórico onde pontifica o Dasein e a sua individualidade, onde sobressai a noção de identidade, de existência - traves que sustentavam a perspetiva kierkegaardiana. Mas, precisamente, é ainda uma tradição religiosa que dá importância ao indivíduo e ao seu "destino"; é ainda ela que enfatiza o modo de ser único, insubstituível, que marca as noções heideggerianas.

Um desafio maior é, por conseguinte, o de se considerar que subjaz a Ser e Tempo e a toda a descrição das estruturas existenciárias, uma preocupação com o Dasein e com o seu destino, quer dizer, a sua identidade que se resume em saber quem é. Como escreve Heidegger no livro sobre Kant, "mais 
original que o homem é a finitude do Dasein nele". No entanto, e paradoxalmente, a abertura ao mundo far-se-á pelo abandono de si - provavelmente o que Heidegger quis dizèr posteriormente à "viragem" - quer dizer, num plano em que a preocupação maior já não é tão-só o destino do Dasein. Se a compreensão do ser pressupõe a finitude do Dasein, e se foi isso que caiu no esquecimento, importa interrogar se o reassumir dessa mesma finitude nos permitirá aceder compreensivamente ao ser. Ou ainda: Não haverá uma dimensão outra, insuspeitável, que desabrochará de uma finitude assumida radicalmente? $\mathrm{E}$ se repugna à ontologia a ideia de um ser infinito não repugnará também $a$ ideia de um ser finito que seja entendido meramente como oposto à infinitude?

Uma segunda perspetiva é a de interrogar Heidegger se a descoberta da finitude, enquanto estrutura existenciária da temporalidade original, não dependerá da minha relação com os outros. Invertendo a perspetiva heideggeriana, descubro a morte própria a partir da morte dos outros - e não a descobriria se os outros não morressem. Esta consideração relembra-nos que o grande ausente de Ser e Tempo é a figura do desejo. Ainda mais originário que o cuidado é o desejo que o fundamenta: é porque somos seres desejantes que cuidamos das coisas - e se não cuidamos delas, se não nos preocupamos com elas, é ainda por temos (outros) desejos, o que inverte aquilo que se diz em Ser e Tempo. Não se trata, quanto a nós, de antepor a infinitude da lei moral à maneira kantiana, mas sim a de antepor a figura do desejo como aquilo que pode, verdadeiramente, desafiar a perspetiva heideggeriana. Portanto, Espinosa contra Heidegger. Atente-se que, na nossa perspetiva, o viver com os outros, a lei moral, a esperança, nomes que designam essa promessa de infinito que intentam contrapor a Heidegger, têm, na verdade, de ser interpretadas em função do desejo - essa figura que dinamiza todas as outras. O que tanto nos remete para as reflexões de Lacan como de Levinas.

Sabemos, aliás, que o pensador lituano pensava o desejo como aquilo que abre um futuro, quer dizer, que desejo e infinito se relacionam radicalmente. ${ }^{26}$ Se o desejo não é a necessidade, é porque ele se abre para aquilo que está para além da razão e faz estilhaçar o espaço da representação, o que se chama, precisamente, infinito. Com efeito, Levinas defende que em todo o acto de conhecer há uma inadequação intransponível e é ela que indica o infinito. Lévinas estaria certamente de acordo com aquilo que o último Heidegger escreve a propósito da Clareira, do Aberto, e da Alétheia, como se indicasse esse fundo que antecede, permite e determina qualquer representação. É nesta abertura para o infinito que encontramos a figura do desejo; nessa ideia de que "o pensador que tem a ideia de infinito é mais do que ele próprio", o que

${ }^{26}$ Cf. José Manuel Heleno, "Lévinas: Desejo e Infinito". In: O Demónio de Sócrates. Lisboa, Fim de Século Edições, 2006. 
equivale a dizer que "um pensamento que pensa mais do que pensa é desejo" - como se não houvesse desejo que não fosse do absolutamente Outro.

Se a filosofia é ainda um desejo, é o de querer assumir uma tarefa impossível: o de reconhecer o mundo da vida como primordial e desejar transcendê-lo, distanciando-se o suficiente para pensá-lo. Todavia, esta cruz do filósofo, a de querer transcender o mundo e de pensá-lo em totalidade, semethante ao desejo de apreender o impensado que subjaz a todo o pensamento, é uma tarefa paradoxal assinalada pelos limites da razão. Se o mundo foi outrora ordem e medida; se nele se viu a unidade dos entes, a sua hierarquia intransponível, essa imagem parece teimar em perdurar. Mas em vez de se considerar um mundo criado por Deus, distinto dele, capaz de pôr em cena entes inumeráveis, o que importa a Heidegger é a visão de um mundo no qual a dramaturgia divina é substituída pela presença de um ser na cena da Terra e do Céu, de homens e deuses. Assim, mais do que pensar o que está além do mundo, o que importa é essa dramaturgia no próprio jogo inacabado dos entes. O ser heideggeriano é essa figura que é pensada na aurora do mundo, como se fosse ainda um último fôlego de um pensar metafísico que, desejoso de compreender o mundo em totalidade, o ordenasse a partir de um ser que se esquiva e se oferece, que tanto se aproxima como se afasta de qualquer determinação. É neste sentido que ser, mundo e finitude, palavras de ressonância mágico-poética, assinalam uma realidade disseminada noutra realidade, perpetuamente testemunhando a dificuldade em dizer quem somos.

Heraclito afirmou outrora (frag. 197) que "os homens dão sempre mostras de não compreenderem que o logos é como eu o descrevo, tanto antes de o terem ouvido como depois....". 27 E no fragmento 199: "Dando ouvidos não a mim mas ao logos, é avisado concordar que todas as coisas são uma". A grande maioria dos homens é incapaz de descobrir esta verdade que é comum, ou seja, válida para todos e acessível a todos. O logos tem, para alguns intérpretes, a mesma extensão que o constituinte cósmico primário, o fogo. ${ }^{28}$ E no fragmento 220, é atribuída a Heraclito a afirmação seguinte:

Esta ordem do mundo (a mesma de todas) não a criou nenhum dos deuses nem dos homens, mas sempre foi e é e será: um fogo eternamente vivo, que se acende com medida e com medida se extingue.

Também é dito no fragmento 222:

Todas as coisas são uma troca igual pelo fogo e o fogo por todas as coisas, como as mercadorias o são pelo ouro e o ouro pelas mercadorias.

${ }^{27}$ Cf. G. S. Kirk e J. E. Raven, Os Filósofos Pré-Socráticos. Lisboa: Fundação Calouste Gulbenkian, 1979.

${ }^{28}$ Ibid., p. 190. 


\section{Escrevem Kirk e Raven:}

[A sabedoria] consiste em compreender o logos, a estrutura análoga ou elemento comum da disposição das coisas, que incorpora o métron ou medida, sendo esta a garantia de que a mudança não produz uma pluralidade desconexa e caótica. ${ }^{29}$

Se as palavras de Heraclito ainda ressoam, é porque nelas se manifesta esse pensar essencial que tanto apaixonou Heidegger. Esse pensar que quer dar a palavra ao logos, que fala na sua compreensão como testemunho da sabedoria - e os pensadores essenciais dizem sempre o mesmo, como escreve Heidegger na Carta sobre o Humanismo - e em que se considera a sua unidade, esse elemento comum que dispõe as coisas, é porque a escuta dos pré-socráticos é a aurora de um pensamento que se extraviou. Mas não há, neste sentido, novidade no pensamento heideggeriano. No ser escuta-se ainda o logos e o fogo heraclitiano, como se o ser fosse esse ouro que trocamos pela mercadoria dos entes.

Na Carta sobre o Humanismo, afirma-se que o "ser está ainda à espera de que ele mesmo se torne digno de ser pensado pelo homem". E mais à frente escreve-se:

A metafisica pensa o homem a partir da animalitas; ela não pensa em direcção da sua humanitas. ${ }^{30}$

Compreendemos então que, cada vez mais, pensar o mundo e a finitude é pensar a aventura do ser que, no seu destino historial, escreve ambas as histórias. Se, decididamente, nos situássemos num plano em que, mais do que homens e mundo, há ser, isso significa a humildade do pensar e a disponibilidade para o sagrado. Mas como se escreveria então a história do mundo e da finitude humana se acaso retomássemos a pergunta pelo sentido do ser que a metafisica esqueceu? Que história é essa que os vindouros poderão contar? No tom apocalíptico que perpassa na Carta sobre o Humanismo, mais do que o real, é do ser que se trata. Atrever-nos-íamos a dizer que esse tom é ainda o da metafísica, onde sagrado e revelação, deuses e homens, ser e ente, traçam a sua história? Por mais estranho que pareça, o perigo que nos atemoriza na era da técnica, a errância ocasionada pelo esquecimento do ser, indicam uma tonalidade metafísica a que o leitor da Carta sobre o Humanismo não se consegue esquivar - e lembremo-nos que ela foi endereçada em 1946 a Jean Beaufret.

${ }^{29}$ Ibid., p. 207.

${ }^{30}$ Heidegger, Lettre sur l'humanisme. Paris : Aubier-Montaigne, 1964 (cf. Tradução portuguesa de Arnaldo Stein, Carta sobre o Humanismo. Lisboa: Guimarães Editores, 1973, pp. 54-55). 
Mas o ser - que é o ser? Ele é ele mesmo. Experimentar isto e dizê-lo é a aprendizagem pela qual deve passar o pensar futuro. $\mathrm{O}$ «ser» - isto não é Deus, nem um fundamento do mundo. ${ }^{31}$

Só quando o ser for experimentado na sua verdade é que começa a "superação da apatridade, na qual erram perdidos, não apenas os homens, mas também a essência do homem". Resta saber qual o mundo e a finitude que encontraremos se acaso regressarmos à pátria. Se o "«mundo" é a clareira do ser na qual o homem penetrou a partir da condição de ser-jogado de sua essência", ${ }^{32}$ apetece dizer, parafraseando Heraclito, que ele foi, é e será, um mistério eternamente vivo que se acende com medida e com medida se extingue.

\section{Referências}

BIEMEL, Walter (1950). Le Concept de Monde chez Heidegger. Paris: Vrin.

HedegGer (1964). Lettre sur l'humanisme. Paris: Aubier-Montaigne. (Tradução portuguesa de Arnaldo Stein, Carta sobre o Humanismo. Lisboa: Guimarães Editores, 1973.)

HeDEGGER (1977). Sein und Zeit. Frankfurt am Main: Vittorio Klostermann. (Cf. Tradução francesa, fora de comércio, de Emmanuel Martineau, Être et temps.)

HEDEGGER (1981). Kant et le problème de la métaphysique. Paris: Tel/Gallimard.

HEDEGGER (1992). Interprétations phénoménologiques d'Aristote. Mauvezin: TransEurop-Repress (edição bilingue).

HEDEGGER (1992). Les concepts fondamentaux de la métaphysique. Monde - finitude - solitude. Paris: Éditions Gallimard.

HeIDEgGer (1997). Estudios sobre Mística Medieval. México: Fondo de Cultura Económica. (GA: Vol. 60: (1995), Phänomenologie des religiösen Lebens.)

Hemegger (1999). Ontologia. Hermenéutica de la Facticidad, Madrid: Alianza Editorial.

HeIDEGger (2002). Caminhos de Floresta. Lisboa: Fundação Calouste Gulbenkian.

HEIDEGGER (2005). La idea de la filosofia y el problema de la concepción del mundo. Barcelona: Herder.

Heleno, José M. (2006). Lévinas: Desejo e Infinito. In: $O$ Demónio de Sócrates. Lisboa: Fim de Século Edições.

LARIVÉE, Annie \& LEDUC, Alexandra (2001). Saint Paul, Augustin et Aristote comme sources gréco-chrétiennes du souci chez Heidegger. Elucidation d'un passage d'Être et Temps ( $§ 42$ Note). Philosophie, «Heideggen», n. ${ }^{\circ}$ 69. Paris: Les Éditions de Minuit.

32 Ibid., p. 99. 
KIRK, G. S. \& Raven, J. E. (1979). Os Filósofos Pré-Socráticos. Lisboa: Fundação Calouste Gulbenkian.

SAFRANSKI, Rüdiger (1996). Heidegger et son temps. Paris: Grasset.

SLOTERDIJK, Peter (2006). La politique de Heidegger. Magazine littéraire, 9 (marsavril).

\begin{abstract}
Our goal is to reflect about heidegger's conception of world and finitude. We analyse some features of heidegger's works before Sein und Zeit, particularly the notion of Dasein and the es gibt. The other moment of our reflection is the relation between world, finitude and time. We finalize writing some critical remarks, recalling the philosophy of Heraclitus and the complicity between logos and Sein.
\end{abstract}

